\title{
Analysis of Principals' Decision-Making: A Literature Study
}

\author{
Hardianto' ${ }^{1}$, Zulkifli ${ }^{2}$, Hidayat ${ }^{3}$ \\ DOI: $10.35445 /$ alishlah.v13i3.1353
}

\begin{tabular}{l} 
Article Info \\
\hline \\
Keywords: \\
Effectiveness; \\
Decision making; \\
Principal
\end{tabular}

Kata kunci:

Efektivitas;

Pengambilan keputusan; Kepala sekolah;

\begin{abstract}
This research was conducted to analyze the decision making by the principal. The analysis is carried out on the stages of decision making, influencing variables and factors, so that decision making is better. Effective decision making will make the school able to realize its vision and goals. This research uses the literature study method. The main source of research data is articles on school principals' decision-making obtained from Google Scholar. The technique of data collection is done by the method of documentation. The results showed that the principal has carried out the decision-making process by following six decision-making steps: problem identification, gathering information, developing alternative solutions, choosing the best alternative, implementing alternatives, and evaluating decisions. There are five variables that influence decision making by the principal. The five variables are selfefficacy, administration knowledge, management information system, emotional quotient and personality. Decision-making by the principal will be more effective by involving teachers and education staff.
\end{abstract}

\begin{abstract}
Abstrak
Penelitian ini dilakukan untuk menganalisis pengambilan keputusan oleh kepala sekolah. Analisis dilakukan terhadap tahapan pengambilan keputusan, variabel yang mempengaruhi serta faktor agar pengambilan keputusan menjadi lebih baik. Pengambilan keputusan yang efektif akan menjadikan sekolah mampu mewujudkan visi dan tujuannya. Penelitian ini menggunakan metode studi kepustakaan. Sumber utama data penelitian adalah artikel tentang pengambilan keputusan oleh kepala sekolah yang diperoleh dari google scholar. Teknik pengumpulan data dilakukan dengan metode dokumentasi. Hasil penelitian diketahui bahwa kepala sekolah telah melakukan proses pengambilan keputusan dengan mengikuti enam langkah pengambilan keputusan, yaitu identifikasi masalah, mengumpulkan informasi, mengembangkan alternatif pemecahan, memilih alternatif terbaik, melaksanakan alternatif dan mengevaluasi keputusan. Terdapat lima variabel yang mempengaruhi pengambilan keputusan oleh kepala sekolah. Lima variabel itu adalah self-efficacy, administration knowledge, management information system, emotional quotient and personality. Pengambilan keputusan oleh kepala sekolah akan lebih efektif dengan melibatkan guru dan tenaga kependidikan.
\end{abstract}

\footnotetext{
${ }^{1}$ Universitas Pasir Pengaraian, Pasir Pengaraian, Indonesia Email: hardiantocally@gmail.com

${ }^{2}$ Universitas Pasir Pengaraian, Pasir Pengaraian, Indonesia Email: zulkifli@upp.ac.id

3 Universitas Pasir Pengaraian, Pasir Pengaraian, Indonesia Email: hidayatrangkuti@gmail.com
} 


\section{INTRODUCTION}

School is an institution specifically designed to educate the nation's children. The progress of a nation is primarily determined by the quality of education of its citizens. Efforts to create quality schools certainly need to be made. The higher the quality of the school, the better the quality of the generation it produces. A school principal leads the school in carrying out its activities.

Principals play an essential role in realizing school goals. They have the main task of realizing the vision and goals optimally. In carrying out these tasks, it takes the ability to make quick and appropriate decisions. The effectiveness of decision-making greatly determines the success of the principals' tasks. Effective decisions can be seen from the quality of decisions and acceptance of these decisions (Putra, 2014).

The principals have five responsibilities: responsibility as a human being, responsibility as a citizen and public servant, responsibility as an educator, responsibility as an educational administrator, and responsibility as an educational leader (Cherkowski, Walker, \& Kutsyuruba, 2015). The implementation of this responsibility also requires the ability to make decisions. Ineffective decision making will cause duties not to be carried out properly.

Today, there are many problems regarding the ineffectiveness of decisions taken by school principals. This lack of effectiveness can be caused by a lack of time in making decisions or taking too long to make decisions. In addition, it is less effective in terms of inaccurate decisions taken to solve a problem. Making a wrong decision will certainly have a negative impact on the achievement of the school's vision and goals.

Decision making is a conscious process of making choices among alternatives to move toward some desired state of affairs (McShane \& Glinow, 2010). Another opinion expressed by Schemerhorn is that decision making is the process of choosing a preferred course of action from a set of alternatives. But the full problem-solving process is not complete until action has been taken to do what is necessary to implement the decision and correct a performance deficiency or properly explore an opportunity (Schemerhorn, 2007). Based on the opinion above, it is known that decision making is a process of determining the choice of several alternatives based on certain considerations.

Some of the principal decision-making problems have gone viral in the community. Among them, the principal was wrong in making decisions about the students' parade clothes. This is like an individual principal who makes decisions by bringing students to a parade resembling a radical group (Sasongko, 2018). The decision to bring students to resemble radical groups in the parade naturally caused controversy. The principal should not make decisions that can create a noisy atmosphere in the community. Moreover, the notion of radicalism has become a real threat to the world.

Furthermore, there are still many illegal levies in schools that are the principal's decision. There are no less than 58 types of illegal levies in schools (Suhendro, 2020). The government has basically banned schools, especially public schools, from collecting fees from parents. Misunderstanding the rules causes the decisions taken to be contrary to the applicable rules. Some school principals still charge students' parents. This incident certainly led to the ineffectiveness of the principal's decision.

This research focuses on finding out how effective decision making by school principals' in Indonesia is and seeing the factors that influence decision making. This research is different from previous research. Previous research has focused more on the decision-making process, such as research (Murtiningsih \& Lian, 2017), (Sangkota, 2018), (Suhaimi \& Khalik, 2018), (Putra, 2014) and (Yanti, 2013). In addition, previous studies only describe factors that influence school principals' decision making such as research (Budiono \& Wening, 2021), (Saputra, Copriady, \& Sumardi, 2017) and (Suryani, Mukhtar, \& Matin, 2018). This research is more comprehensive by analyzing the principal's effectiveness of decision-making. In this study, three research questions were asked, namely about the effective decision-making process by the principal, the influence of the principals' 
decision making, and factors that are important to consider in making effective school principals' decisions. In carrying out their duties, the principal will always make decisions. Improper decisions or late decisions will greatly interfere with achieving school goals. Therefore, effective decision making is necessary. Seeing the problems above, the authors are interested in describing the principal's decision-making effectiveness.

\section{METHOD}

This research method is library research. Literature research is research conducted by reading, recording and processing materials from various sources (Zed, 2008). Literature research is carried out by looking at research materials structured with certain techniques and methods (WN George, 2008). Data collection is done by documentation technique. This research was conducted by looking at the literature review from various sources. The selected reading sources come from national and international journals. Specially selected articles that discuss decision making by school principals in Indonesia. The research article was taken from the key words "kepala sekolah", "pengambilan keputusan", "pengambilan keputusan oleh kepala sekolah" and "decision by principal". Article obtained through https://scholar.google.com and collected 24 articles. All articles are grouped based on similarities and arranged in a single unit. The similarity of the articles can be seen from the research questions asked. Found 8 articles that discuss the decision-making process by the principal, 7 articles that discuss the influence of a variable on decision making and 8 articles that discuss the factors that influence the principal's decision-making. The results of grouping research findings are analyzed to obtain a conclusion.

\section{FINDINGS AND DISCUSSION}

The results of the study found twenty-four articles that discussed decision making by school principals in Indonesia. The articles found can be seen in the following Table:

\section{Table 1. Summary of Research Results of Decision Making by School Principals'}

\begin{tabular}{|c|c|c|c|}
\hline No & Author & Design & $\begin{array}{c}\text { Research Findings According to } \\
\text { Research Questions }\end{array}$ \\
\hline 1 & $\begin{array}{l}\text { M. Nasrullah et.al } \\
\text { (2017) }\end{array}$ & Quantitative & $\begin{array}{l}\text { There is an effect of principal's decision } \\
\text { making on teacher performance }\end{array}$ \\
\hline 2 & Sangkota (2018) & Explanatory research & $\begin{array}{c}\text { Decision making by principals is carried out } \\
\text { in six stages }\end{array}$ \\
\hline 3 & $\begin{array}{l}\text { Suhaimi \& Khalik } \\
\text { (2018) }\end{array}$ & Qualitative (Case study) & $\begin{array}{l}\text { The decision-making process is carried out in } \\
\text { six stages democratically }\end{array}$ \\
\hline 4 & Rohiyatun (2016) & Library research & $\begin{array}{l}\text { Teacher involvement in making decisions is } \\
\text { very important because it tends to lead to } \\
\text { higher quality decisions }\end{array}$ \\
\hline 5 & Hayati et.al (2021) & Library research & $\begin{array}{c}\text { Decisions can be made individually and in } \\
\text { groups }\end{array}$ \\
\hline 6 & $\begin{array}{l}\text { Budiono \& Wening } \\
\text { (2021) }\end{array}$ & Quantitative & $\begin{array}{l}\text { Emotional intelligence has a positive and } \\
\text { significant effect on decision making }\end{array}$ \\
\hline 7 & $\begin{array}{l}\text { Murtiningsih \& Lian } \\
\text { (2017) }\end{array}$ & Qualitative & $\begin{array}{l}\text { Decision making has been done well } \\
\text { following six stages of decision making }\end{array}$ \\
\hline 8 & Qiptiah (2019) & Qualitative & $\begin{array}{c}\text { Decision making model organized sir and } \\
\text { disorganized }\end{array}$ \\
\hline 9 & Muslim (2018) & Qualitative & $\begin{array}{c}\text { Participatory decision-making affects teacher } \\
\text { performance }\end{array}$ \\
\hline 10 & Yanti (2013) & Quantitative & $\begin{array}{l}\text { Decision making is good by following the } \\
\text { stages of decision making }\end{array}$ \\
\hline 11 & Rahayu (2014) & Library research & $\begin{array}{c}\text { Efforts to improve decision-making abilities } \\
\text { can be done by increasing expertise, } \\
\text { intelligence, creativity and maintaining } \\
\text { emotional stability. }\end{array}$ \\
\hline
\end{tabular}




\begin{tabular}{|c|c|c|c|}
\hline 12 & Putra (2014) & Quantitative & $\begin{array}{l}\text { The decision-making process has been } \\
\text { effective with six steps of decision-making }\end{array}$ \\
\hline 13 & $\begin{array}{l}\text { Permadani et.al } \\
\qquad(2018)\end{array}$ & Qualitative & $\begin{array}{l}\text { Factors supporting the effectiveness of } \\
\text { decision-making are the openness of all } \\
\text { parties and freedom of opinion }\end{array}$ \\
\hline 14 & Kurniawan (2018) & Qualitative & $\begin{array}{l}\text { Decision-making by the head schools seen } \\
\text { from programmed decisions and non- } \\
\text { programmed decisions }\end{array}$ \\
\hline 15 & Saputra et.al (2017) & Quantitative & $\begin{array}{c}\text { There is an influence of emotional } \\
\text { intelligence and the use of MIS on decision } \\
\text { making }\end{array}$ \\
\hline 16 & Sari (2015) & Quantitative & $\begin{array}{l}\text { In making decisions, principals need to ask } \\
\text { teachers for advice }\end{array}$ \\
\hline 17 & Sinaga et.al (2018) & Quantitative & $\begin{array}{l}\text { There is a relationship between } \\
\text { administrative knowledge and self-efficacy on } \\
\text { decision making }\end{array}$ \\
\hline 18 & Fariha (2013) & Qualitative & $\begin{array}{l}\text { The supporting factor for decision making is } \\
\text { the coordination between school principals, } \\
\text { teachers and education staff }\end{array}$ \\
\hline 19 & $\begin{array}{l}\text { Nai and Wijayanti } \\
(2018)\end{array}$ & Qualitative & $\begin{array}{l}\text { Decision making in schools can be done by } \\
\text { teacher council meetings and education staff }\end{array}$ \\
\hline 20 & $\begin{array}{c}\text { Triharsiwi \& } \\
\text { Pratomo (2020) }\end{array}$ & Qualitative & $\begin{array}{c}\text { Decision making would be better involving } \\
\text { teachers }\end{array}$ \\
\hline 21 & Suryani et.al (2018) & Quantitative & $\begin{array}{l}\text { Personality and self-efficacy affect decision } \\
\text { making }\end{array}$ \\
\hline 22 & Handayani (2021) & Quantitative & $\begin{array}{l}\text { There is a positive relationship involving } \\
\text { teachers in decision making with a passion } \\
\text { for teaching }\end{array}$ \\
\hline 23 & Rahmawati (2018) & Qualitative & $\begin{array}{l}\text { Teacher empowerment is important in } \\
\text { decision making }\end{array}$ \\
\hline 24 & Annisya et.al (2021) & Qualitative & $\begin{array}{l}\text { Cross-channel communication will support } \\
\text { good decision making }\end{array}$ \\
\hline
\end{tabular}

\section{Decision Making Process}

The effectiveness of decision making is first seen from the decision-making process. Decisionmaking activities are basically routine activities for each individual. Every day someone will always make a decision in his life. Moreover, a school principal who has a personal life goal and is responsible for realising the school's vision will always make decisions. The most important task of a school principal is to make decisions (Qiptiah, 2019). The progress of a school depends on every decision taken by the principal.

In making a decision, there are at least three stages or processes. Simon suggests that the three stages are intelligence activity, design activity and choice activity (George \& Jones, 2012). Intelligence activity is the stage of a decision-maker describing the environmental conditions in which the decision was taken. Design activity is an activity in finding the main problem and analyzing the problem. The activity of choosing is choosing several possible choices available.

The principal must always hone intelligence, design and choice activities. Routine decisions are certainly easier to make than incidental decisions. In intelligence activities, principals need sufficient information about school conditions. Information can be obtained when the school has a reliable information system. Design activities require experience to be easier to perform. The participation of teachers and education personnel can also be done in this activity. However, minimizing the number of people involved in decision-making is also necessary for certain problems. This choice activity really requires experience. The new principal is usually more difficult at this activity.

A more complex opinion was put forward by McShane and Von Glinow, who mentioned six stages in decision making. The stages identify a problem or opportunity, choose the best decision 
process, develop alternative solutions, choose the best alternative, implement the selected alternative and evaluate decision outcomes (McShane \& Glinow, 2010). In the first stage, decisionmakers identify problems and recognize opportunities from these problems. Every problem is an opportunity to decide to improve the situation.

The second stage looks at the decision process by considering the information needed to solve the problem. In making decisions, the adequacy of information is very important. Therefore, information systems play an important role in realizing quick and appropriate decisions. This stage is closely related to the third stage, namely developing alternatives. With more information, it will be possible to make various alternatives in solving problems.

The fourth stage is to choose an alternative among several existing alternatives. The more choices, the more difficult it will be to choose. However, with many choices will provide a greater opportunity to solve problems better. The ability to choose this alternative must be based on careful consideration and concerns the organisation's interests.

The fifth stage is implementing alternatives. The best decisions are decisions that are implemented. After the alternative is selected, it must be implemented properly. The sixth stage is evaluating the decision. Each decision must be evaluated to see the level of success of the decision. The evaluation results can provide an overview and input in further decision making.

The principal will always pass these six stages in making a decision. The ability to master these stages is absolutely necessary. Therefore, to become a reliable principal, it is very important to master the ability to make decisions. The implementation of the Program Pelatihan Kepala Sekolah (PPKS) must be improved so that the principal's mistakes in decision making do not happen again.

In general, principals in Indonesia have implemented these steps in making decisions. Some research results state that principals in making decisions follow these six steps. This is in accordance with research (Murtiningsih \& Lian, 2017), (Sangkota, 2018), (Suhaimi \& Khalik, 2018), (Putra, 2014) and (Yanti, 2013). In making decisions, the principal can do it himself or involve teachers and education staff (Hayati, Zulvira, \& Gistituati, 2021). Decisions taken by the principal can come from routine or organized problems and incidental or unorganized problems (Kurniawan, 2018) and (Qiptiah, 2019)

\section{Variables Affecting Decision Making by Principals}

Based on the study results, it is known that several variables affect principals' decision-making. Personality has a positive and significant effect on decision making (Suryani et al., 2018). The personality in question is the style or characteristic that a person has. The better the personality of a school principal, the more correct the decisions he makes.

Administrative knowledge also influences decision making (Sinaga, Saam, \& Junus, 2018). The more knowledge a principal has with administrative knowledge, the better his decision making will be. Other variables that influence decision making are self-efficacy (Sinaga et al., 2018) and (Suryani et al., 2018). Self-efficacy is a person's belief in his ability to do a job. Principals who have high selfefficacy will be better at making decisions.

Emotional intelligence influences decision making (Budiono \& Wening, 2021) and (Saputra et al., 2017). Principals who have high emotional intelligence will be better at making decisions. The utilization of Management Information Systems (MIS) also affects the decision making of school principals (Saputra et al., 2017). The utilization of a good Management Information System will improve the principal's quality of decision-making. Therefore, it is important for school principals to have good emotional intelligence and use a reliable MIS.

Further research is related to the influence of decision-making variables on teacher performance. Effective principal decision-making will improve teacher performance (Nasrullah, Rumingan, Nasaruddin, \& Niswaty, 2017). This is also in accordance with the study results (Muslim, 2018). Based on the results of this study, it is known that good decision making will improve teacher 
performance. For more details, the results of research on decision making by school principals that have been carried out previously can be seen in the following figure 1 :

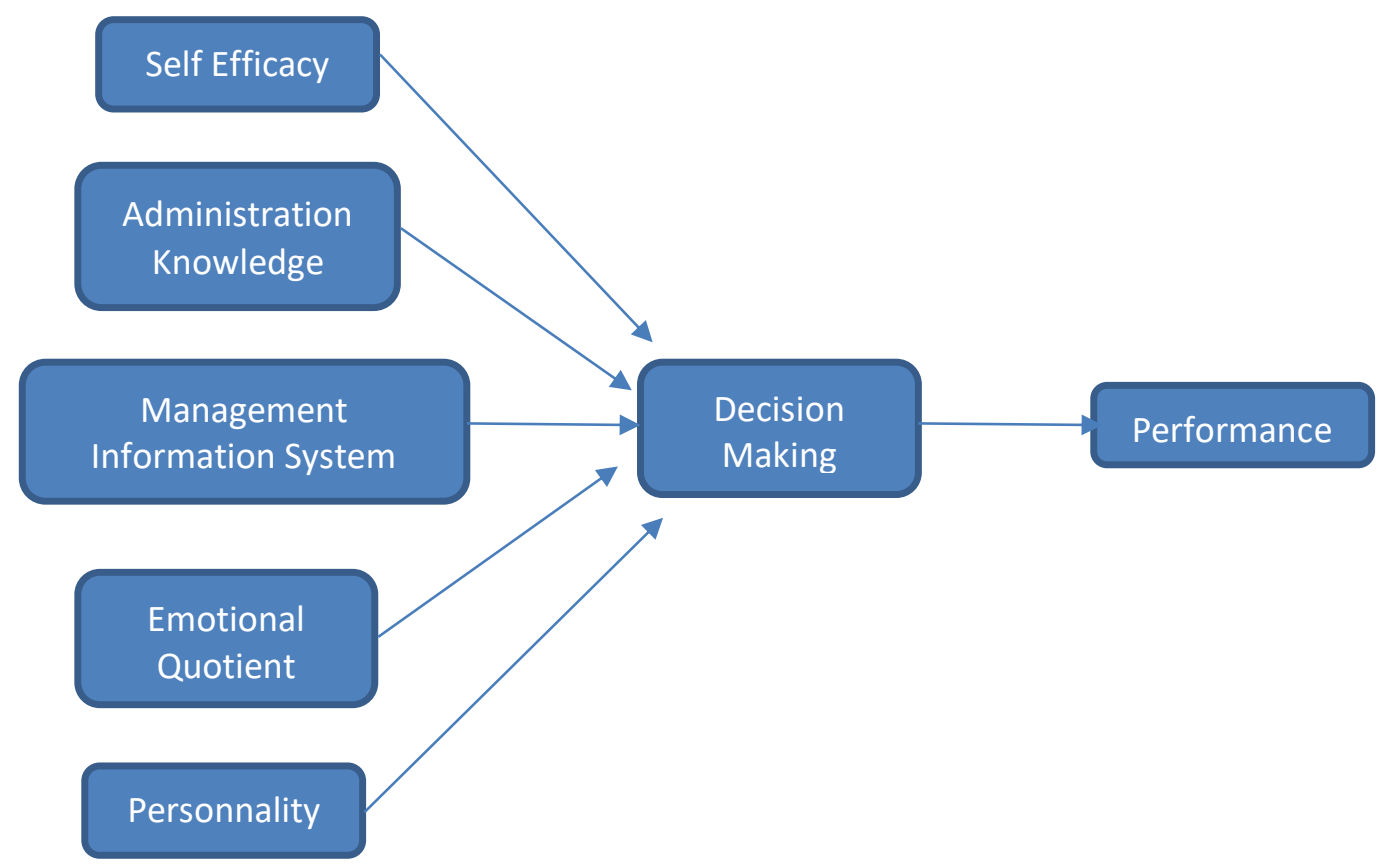

Figure. 1. Research on Decision Making by Principals.

Based on the research findings, it is known that five variables have a positive and significant effect on decision making by the principal. The five variables are self-efficacy, administration knowledge, emotional quotient, Management Information System and Personality. To improve the quality of decision-making, it can be done by increasing self-efficacy, administration knowledge, emotional quotient, Management Information System and Personality of the principal. Effective decisions from school principals will improve teacher performance.

\section{Factors that Determine the Effectiveness of Principals Decision Making}

Decisions are important in realizing educational goals. For the principal's decision to be effective, it is necessary to involve the teacher council and education staff. When teachers and education personnel are involved in making decisions, acceptance of decisions is better. Some research results state that the most important factor in determining the effectiveness of decision making is the involvement of teachers and education personnel (Fariha, 2013), (Nai \& Wijayanti, 2018), (Rohiyatun, 2016), (Sari, 2015) dan (Triharsiwi \& Pratomo, 2020).

Decision-making involving teachers will cause teachers to be more enthusiastic in teaching (Handayani, 2021). In addition, involving teachers in making decisions can increase teacher job satisfaction which ultimately improves the quality of education (Rahmawati, 2018). Therefore, the involvement of teachers and education personnel in making decisions is very important for school principals. In involving teachers in making decisions, cross-channel communication is needed (Annisya, Susilo, \& Sugeng, 2021). This means that communication between principals and teachers uses one channel.

The involvement of teachers in making decisions can be done using brainstorming techniques, nominal groups and quality groups (Muslim, 2018). The brainstorming technique is how teachers and education personnel provide suggestions or suggestions in making decisions. The nominal group technique is to ask for the opinion of a limited number of teachers or education personnel who are 
considered to best understand the problems that occur. The quality group technique is where the principal forms a quality team that will provide input in solving a problem.

In making effective decisions, principals must be able to maintain emotional stability and increase creativity. In addition, it takes courage to make decisions and increase intelligence (Rahayu, 2014). Decisions made with emotion will make the quality of the decision bad. So that new problems that could be bigger can occur. The freedom of opinion and openness of all parties is also the key to making effective decisions (Permadani, Maisyaroh, \& Mustiningsih, 2018).

\section{CONCLUSION}

Based on the discussion above, it can be concluded that the effectiveness of decision-making by school principals in Indonesia in terms of the decision-making process has been carried out well. The principal has implemented six stages of making a decision. Five variables influence the principal's decision making, namely self-efficacy, emotional quotient, personality, administration knowledge and Management Information System (MIS). An important factor for making effective school principal decisions is to involve teachers and education personnel in making decisions. This article implies that principals in making decisions require sufficient information and need administrative knowledge, self-efficacy and emotional quotient. The next researcher can examine the principal's decision making based on the level of education.

\section{REFERENCES}

Annisya, M., Susilo, \& Sugeng. (2021). Decision Making by Principal Based on Cross-Channel Communication Models at SD IT Samarinda. Jurnal Impian, 1(1), 31-38.

Budiono, \& Wening, N. (2021). Dampak Kecerdasan Emosi Terhadap Kualitas Pengambilan Keputusan Pemimpin Dan Efektivitas Sekolah Di Indonesia. Jurnal IKRA-ITH Humaniora, 5(1), 59-66.

Cherkowski, S. L., Walker, K. D., \& Kutsyuruba, B. (2015). Principals' Moral Agency and Ethical Decision-Making: Toward a Transformational Ethics. International Journal of Education Policy \& Leadership, 7, 1-17.

Fariha. (2013). Pengambilan Keputusan Strategis Kepala SMK Negeri 1 Tolitoli. Jurnal Eklektika, 1(1), 103-114.

George, J. M., \& Jones, G. R. (2012). Understanding and Managing Organizatinal Behavior. New Jersey: Pearson.

Hayati, F., Zulvira, R., \& Gistituati, N. (2021). Lembaga pendidikan: kebijakan dan pengambilan keputusan. Jurnal Riset Tindakan Indonesia, 6(1), 100-104.

Kurniawan, Y. A. (2018). Kepemimpinan Kepala Sekolah (Studi Kasus di SMP Kolese Kanisius Jakarta). Jurnal Manajemen Pendidikan, 9(1), 182-190.

McShane, S., \& Glinow, M. A. Von. (2010). Organizational Behavior Emerging Knowledge and Practice for The Real World (5th ed.). New York: McGraw Hill.

Murtiningsih, \& Lian, B. (2017). Proses Pengambilan Keputusan Kepala Sekolah Terhadap Peningkatan Kinerja Guru SMP. Jurnal Manajemen Kepemimpinan Dan Supervisi Pendidikan, 2(1), 87-96.

Muslim, A. (2018). Pengambilan Keputusan Partisipatif Kepala Sekolah di MTS NW Nurul Ihsan Tilawah. Jurnal Paedagogy, 5(1), 79-83.

Nai, H., \& Wijayanti, W. (2018). Pelaksanaan Tugas dan Fungsi Kepala Sekolah Pendidikan Menengah Negeri. Jurnal Akuntabilitas Manajemen Pendidikan, 6(2), 183-192.

Nasrullah, M., Rumingan, M., Nasaruddin, \& Niswaty, R. (2017). Pengaruh Pengambilan Keputusan Kepala Sekolah terhadap Kinerja Guru di SMK Negeri 1 Makassar. Jurnal Administrate:Jurnal Pemikiran Ilmiah Dan Pendidikan Administrasi Perkantoran, 4(2), 103-110.

Permadani, D. R., Maisyaroh, \& Mustiningsih. (2018). Kepemimpinan Kepala Sekolah dalam 
Pembuatan Keputusan. Jurnal Administrasi Dan Manajemen Pendidikan, 1(3), 320-326.

Putra, V. M. (2014). Persepsi Guru Terhadap Pengambilan Keputusan Kepala Sekolah di SMK Negeri Kelompok Bisnis Manajemen Kota Padang. Bahana Manajemen Pendidikan, 2(1), 755-831.

Qiptiah, D. M. (2019). Model Pengambilan Keputusan Kepala Sekolah di MTS Irsyadud Diniyah Kabupaten Probolinggo. Jurnal Tarlim, 21(71-84).

Rahayu, P. (2014). Peningkatan Kemampuan Kepala Sekolah Dalam Mengambil Keputusan. Bahana Manajemen Pendidikan, 2(1), 550-557.

Rohiyatun, B. (2016). Analisis Keterlibatan Guru Dalam Pengambilan Keptusan (Kajian Teoritis Organisasi Sekolah). Jurnal Visionary, 1(1), 130-134.

Sangkota, H. (2018). Analisis Proses Pengambilan Keputusan Kepala Sekolah Menengah Negeri Sekecamatan Luwuk Kabupaten Banggai Sulawesi Tengah. Linear, 2(1), 21-30.

Saputra, B., Copriady, J., \& Sumardi. (2017). Pengaruh Kecerdasan Emosional dan Pemanfaatan Sistem Informasi Manajemen Terhadap Pengambilan Keputusan Kepala Sekolah Dasar di UPTD Kecamatan Tampan Kota Pekanbaru. Jurnal Manajemen Pendidikan, 5(2), 201-212.

Sari, A. M. (2015). Persepsi Guru Tentang Pengambilan Keputusan yang Dilakukan Kepala Sekolah di SMK Negeri 2 Padang. Bahana Manajemen Pendidikan, 3(1), 701-706.

Sasongko, D. (2018). Sebelum dicopot Kepsek TK Muridnya Bercadar Sudah Diperingatkan. Merdeka.Com.

Schemerhorn, J. R. (2007). Management and Organizational Behavior. New York: John Willey and Sons.

Sinaga, P., Saam, Z., \& Junus, N. (2018). Hubungan Antara Pengetahuan Administrasi dan SelfEfficacy Dengan Pengambilan Keputusan Kepala Sekolah Pada SD Se-Kecamatan Bagan Sinembah. Jurnal Manajemen Pendidikan, 6(1), 105-115.

Suhaimi, \& Khalik, A. (2018). Kepemimpinan Transformasional Kepala Sekolah pada SMP Muhammadiyah 4 Banjarmasin. Jurnal Penelitian Tindakan Dan Pendidikan, 4(1), 37-46.

Suhendro, B. (2020). Ini 58 Jenis Pungli Di Sekolah, Masyarakat Jangan Takut Lapor Polisi. Inijabar.Com.

Suryani, A. M., Mukhtar, M., \& Matin. (2018). Pengaruh Kepribadian dan Efikasi Diri Terhadap Pengambilan Keputusan Kepala SMA Negeri Di DKI Jakarta. Jurnal Ilmiah Wawasan Pendidikan, 4(3), 19-26.

Triharsiwi, \& Pratomo, W. (2020). Karakteristik Tipe Pengambilan Keputusan Anggaran Kepala Sekolah. Jurnal Taman Cendikia, 4(1).

Yanti, H. (2013). Proses Pengambilan Keputusan Kepala Sekolah Terhadap Peningkatan Kinerja Guru SMP. Bahana Manajemen Pendidikan, 1(1), 84-92. 